\title{
Miért van szükségünk közösségalapú egészségfejlesztésre?
}

\author{
Why do we need community-based health promotion?
}

\author{
Szerző: Benyó Béla $\bowtie$ \\ Sárospataki Református Teológiai Akadémia; Országos Közegészségügyi Intézet
}

Beküldve: 2017. 11. 14.

doi: 10.24365/ef.v58i4.209

\begin{abstract}
Bevezetés: Az Ottawai Nyilatkozat lendületet és teret adott a közösségalapú egészségfejlesztési elméletek és gyakorlati politikák megfogalmazásának. Azóta számos elmélet és bizonyítottan hatásos beavatkozási módszer látott napvilágot e témakörben. Ezek közül néhány kiállta a gyakorlat próbáját és a jó gyakorlatok sorába került. A kutatók kimerítő vitát folytattak a közösségi bevonódás szintjeiről, módjairól, jellemzőiről, azok egymáshoz való kapcsolódásukról. Tisztázták a közösségi részvétel, felhatalmazottság mibenlétét és folyamatjellegét, amely végül munkadefinícióként a WHO Európai Regionális Irodája által is elfogadást nyert. A közösségi felhatalmazottság fogalmának tisztázása gyakorlati jelentőséggel bír, mert meghatározza a közösség szerepét az egészségfejlesztés során, melynek jelentőségét nehéz túlbecsülni. Ennek eredményeképpen válhat valósággá az az elv, hogy a közösség egészségét alapvetően meghatározza, hogy milyen mértékben képes a közösség kontrollálni az egészségkockázati tényezők alakulását. A változás igénye elérte hazánkat is, a népegészségügy intézményrendszerének reformja a figyelem középpontjába helyezi a közösség szerepének értelmezését. Éppen ezért aktuálissá vált a téma elméleti áttekintése, összefoglalása. A cikk erre tesz kísérletet.
\end{abstract}

Kulcsszavak: egészségfejlesztés; közösségi részvétel; felhatalmazottság; hatalomnélküliség; kapacitásfejlesztés

Introduction: The Ottawa Charter gave an impetus and space to the development of communitybased theories and health promotion practices. Since that numerous theories and evidencebased methods have emerged in this field. Some of them were satisfactory in practice and became part of the good practices. There has been intense debate between researchers on the level of community involvement, its ways, characteristics and their connections. These debates led to the clarification of the meaning of community participation and empowerment arriving at the idea of being a continuum. Finally, this became accepted by the WHO European Regional Office as working definition of empowerment. The clarification of community empowerment has practical benefits since it takes into account the important role played by the community in the process of health promotion, therefore, it is hard to overestimate its significance. As a result of this new approach, it is easy to understand that the health of a community merely depends on to what extent the community is able to control risk factors in health. Hungary realized the need for changes and the planned public health reform focuses on the role of communities and community-based empowerment. Therefore, the need arose to summarize the theories related to community involvement. The article makes an attempt to this.

Keywords: health promotion; community participation; empowerment; powerlessness; capacity building 


\section{BEVEZETÉS}

Az egészségfejlesztésben élenjáró országok szakemberei a '80-as és '90-es években késhegyre menő vitát folytattak a közösségalapú egészségfejlesztés elméleti és gyakorlati kérdéseiről. Ezért az egészségfejlesztés közösségi beágyazottsága, a közösségalapú egészségfejlesztés bővelkedik szakirodalmi forrásokban. A közösségalapú megközelítés gondolata nem véletlenül kapcsolódik azokhoz az országokhoz, amelyek később otthont adtak az egymást követő nemzetközi konferenciáknak. Azok az országok, amelyek nagy kiterjedésűek, mint például Kanada, az USA vagy Ausztrália jelentős közösségi hagyományokkal rendelkezik. Ezekben az államokban a nagy távolságok miatt a központi hatalom mellett egy decentralizált hatalmi struktúra és ennek következtében a decentralizált struktúrákban való gondolkodás is meghonosodott. Így nem meglepő, hogy ezen országok jártak élen a közösségalapú egészségfejlesztési programok megfogalmazásában is. Ez a szemlélet a máig a legnagyobb hatású nemzetközi dokumentumot, az Ottawai Nyilatkozatot is áthatotta. A közösségi részvétel legnagyobb élharcosa a WHO, 1986-ban az Ottawai Nyilatkozatban az öt megnevezett cselekvési terület egyikeként a „közösségi lépések megerősítését” az egészségfejlesztés egyik központi kérdésévé tette. Ezt a törekvést jól példázza az Ottawai Nyilatkozat idevonatkozó része:

„Az egészségfejlesztés a jobb egészségi állapot elérése érdekében - konkrét és hatékony közösségi tevékenységgel - prioritásokat állít fel, döntéseket hoz, stratégiákat tervez és végrehajtja azokat. E folyamat magvát a közösségek hatalommal való felruházása képezi; az, hogy tulajdonosai és irányítói legyenek saját törekvéseiknek és sorsuknak." ${ }^{1}$

Az egymást követő nemzetközi konferenciák (Adelaide, 1988; Sundsvall, 1991; Jakarta, 1997; Mexikó, 2000; Bangkok, 2005) mind foglalkoztak ezzel a témával, és sorra megerősítették a közösség részvételének a fontosságát az egészségfejlesztési politikák megfogalmazásában és végrehajtásában. Így nem meglepő, hogy a Dzsakartai Nyilatkozat is a közösségi szemléletet tekintette kiindulópontnak, amikor a közösségi kapacitás és az egyének hatalommal való felruházásának növelését nevezte meg prioritásként. ${ }^{2}$ Az 1992-es ENSZ Környezet és Fejlődés Konferencia deklarálta, hogy a közösségek aktív részvétele alapvető a környezetvédelmileg, gazdaságilag és társadalmilag fenntartható fejlődéshez és sürgette a helyi hatóságokat, hogy kezdeményezzenek konzultációt és folytassanak konszenzushoz vezető tárgyalásokat állampolgáraikkal, helyi hatóságaikkal és fogalmazzák meg saját fenntartható fejlődési stratégiájukat. Ezt a koncepciót a WHO Európai Regionális Irodája is kiindulópontnak tekintette, amikor megfogalmazta a "Health 21" elnevezésű programot. A dokumentum támogatta a részvételen alapuló egészségfejlesztés folyamatát, azt, amely „felhatalmazza az egyént, a helyi közösségeket, a privát valamint az önkéntes szervezeteket az egészségfejlesztés különböző színterein, pl. otthon, a munkahelyeken, az iskolákban és a városokban". ${ }^{3}$

Természetesen a WHO sem kerülhette meg azt a feladatot, hogy definiálja a közösségi részvétel fogalmát, hiszen elfogadott értelmezés nélkül annak gyakorlatba való átültetése sem lett volna lehetséges. Ezért a WHO Európai Regionális Irodája Bracht és Tsouros, valamint Smithies és Webster elméleti munkáságát alapul véve az alábbi definíciót javasolta a közösségi részvétel fogalmára: ${ }^{4,5}$

„A közösségi részvétel egy folyamat, amelynek eredményeképpen az emberek képessé válnak aktívan és hitelesen részt venni az őket érintő kérdésekben, döntéseket hozni azokról a körülményekről, amelyek meghatározzák életüket, képesek politikákat megfogalmazni és azokat végrehajtani, szolgáltatásokat nyújtani és fejleszteni, valamint változásokat eredményező akciókat szervezni". ${ }^{6}$

A koncepciók körüli viták azóta már elmozdultak a közösségi kapacitás és a szociális kapacitás irányába, de a közösségi felhatalmazottsági mint téma és gyakorlat mit sem veszített fontosságából. A közösségalapú egészségfejlesztés napirendre túzését az teszi aktuálissá hazánkban, hogy évek óta folynak az előkészületek a népegészségügyi intézményrendszer megreformálására, így lehetőségünk adódik figyelembe venni, alkalmazni az e területen

\footnotetext{
'Az angol nyelvben az EMPOWERMENT kifejezés honosodott meg a hatalommal való felruházás fogalmára, amelyre magyarul a „felhatalmazottság” kifejezést használom. Megjegyzendő, hogy a kifejezés egyrészt a hatalommal való ellátottságot, másrészt a tevékenység ellátásához szükséges kompetenciákkal való felvértezettséget is jelenti.
} 
felhalmozódott nemzetközi tapasztalatokat. A Széchenyi Terv keretében 2011-ben kiírt, TÁMOP6.1.2/11/3 és TÁMOP-6.1.2/11/LHH/B kódszámú pályázati felhívások nyomán, jelentős lemaradással ugyan, de Magyarországon is elkezdődött az egészségfejlesztés intézményes átalakítása. Ennek egyik eredménye, hogy 61 egészségfejlesztési iroda jött létre és kezdte meg múködését 2013 és 2014 között. Az intézkedés célja, hogy a járási szintű prevalencia alapján, helyi egészségtervben megfogalmazott, bizonyítottan hatásos beavatkozási módokat dolgozzon ki és ültessen át a gyakorlatba. Ez a folyamat szerencsére nem áll le, ez év nyarán elkezdődött az EFOP 1.8.0 számú projekt, melynek egyik legfontosabb célja kibővíteni és hálózattá szervezni a már korábban létrehozott, egészségfejlesztéssel foglalkozó intézményeket, továbbá egységes szakmai tartalommal, módszertannal megtámogatni őket.

Ez az intézkedés jó alkalom a közösségalapú egészségfejlesztés elméletének áttekintésére: meddig jutottak ebben a témában az élenjáró országok, melyek azok a közösségi elméletek, amelyek markánsan meghatározták az egészségfejlesztési programok tartalmát. Az áttekintésben az a nem titkolt szándék vezet, hogy utat nyissak a jó gyakorlatok magyarországi adaptálása előtt. Jelen írásomban sem az elméletek gyakorlati megvalósításával, sem azok kritikájával, értékelésével nem foglalkozom. Ez alkalommal az egészségfejlesztés közösségi megalapozottságát alátámasztó érveléseket mutatom be: miért van szükség a közösség részvételére, felhatalmazottságra, továbbá hogy ez miképpen befolyásolja az egészségfejlesztési programokat. Ennek keretében részletesen elemzem azokat a koncepciókat, amelyek a közösség bevontságát eredményezik. Mindenekelőtt azonban azt kell tisztázni, hogy miért szükséges a közösség részvétele az egészségfejlesztésben.

\section{INDOKOLA A KÖZÖSSÉG BEVONÁSÁT AZ EGÉSZSÉGFEJLESZTÉSI TEVÉKENYSÉGEKBE?}

Az elmúlt évtizedekben számos elmélet és írás ( $p l$. Schurman, Israel és még sok más szerző) foglalkozott azzal a problémával, hogy miképpen befolyásolja a hatalomnélküliség az egészség-magatartás alakulását, vagy annak ellenkezőjével, miképpen hat a közösség felhatalmazottsága az egyének egészség-magatartására. ${ }^{7,8,9}$ Széles körü - a WHO dokumentumaiban is rögzített - konszenzus alakult ki a különböző egészségfejlesztéssel foglalkozó szerzők között abban, hogy az egészség egyik fontos feltétele, hogy az egyének képesek legyenek kontrollálni az egészségüket befolyásoló kockázati tényezőket. Ez a képesség közösségi szinten leggyakrabban a részvételi formák múködésében ölt testet.

A részvételi formák jelentősége abban van, hogy az interperszonális kapcsolatok kontrollálása révén megteremtik a lehetőségét annak, hogy az egyén képes legyen befolyásolni a döntési folyamatot. A résztvevő saját maga az, aki ebben a folyamatban megszerzi a befolyás lehetőségét, azonosítja a problémát és megoldási javaslattal áll elő. Ez a forma ugyan bevonja az egyént az egészségfejlesztési program megvalósításába, ami cserében fejleszti személyes kapacitásait, kompetenciáit, de nem szükségszerűen eredményezi a közösség megerősödését az életkörülményeket befolyásoló tényezők ellenőrzésében. Ehhez, mint később látni fogjuk közösségi identitásra, közös célok megfogalmazására és véghajtására van szükség.

A participatív technikák fejlődésének következtében ma már nem az a kérdés, hogy szükséges-e, inkább az, hogy egyáltalán képes-e az egyén, és ha igen, milyen mértékben képes az egészségét befolyásoló tényezők kézben tartására. Az egészségi állapotot befolyásoló tényezők között ugyanis szép számmal vannak olyanok is, amelyek túlmutatnak az egyén hatókörén, amelyekre már mint egyén nem képes hatást gyakorolni. Ezek jelentős része társadalmi eredetű, ebből fakadóan kontrollálásuk is csak közösségi, társadalmi szinten képzelhető el. James és más szerzők szerint a részvételi és együttmúködési modellek azt a célt szolgálják, hogy az egyént és a közösséget ellássák a tevékenység eredményességéhez szükséges felhatalmazottsággal. ${ }^{10,32}$ Azonban a megkülönböztető jegy a részvétel és a felhatalmazottság között a folyamat céljában és tartalmában van. A felhatalmazottságnak explicit céljai vannak, nevezetesen szociális és társadalmi változások facilitálása, melyek a mi esetünkben az egészség-magatartás változásában, egészségesebb életfeltételek kialakulásában jelennek meg. Ennek formája pedig a közösségi aktivitás.

A közösségi részvétel szükségessége mellett érvel Rifkin is, amikor azt állítja, hogy egy egészségfejlesz- 
tési programban az érdekgazdákii nagyobb valószínúséggel köteleződnek el akkor, ha nem csupán részt vesznek a döntéshozatalban vagyis participatív a szerepük, hanem inkább akkor, amikor kialakul bennük a "tulajdonosság” érzete, vagyis az számit, hogy a program tulajdonosainak érzik-e magukat vagy csupán a folyamat résztvevőinek. ${ }^{11}$

A közösségi megközelítés előnyeit hangsúlyozza az a szociálpszichológiai megfigyelés is, mely szerint az eltervezett magatartás-változás létrejötte valószínübb, ha az közösségi környezetben történik illetve, fenntarthatóbb, ha az a befogadó közösség jóváhagyásával történik. Ezek alapján jó okunk van azt feltételezni, hogy egészségegyenlőtlenség kezelése amely nélkülözhetetlen tényezője az egészségfejlesztési programoknak - szintén sikeresebb lehet közösségi keretek között hiszen, mint oly sok egyenlőtlenség, ez is társadalmi gyökerű. Úgy is értelmezhetjük, hogy az egészségegyenlőtlenség kialakulása a kockázati tényezők egyenlőtlenségének az eredménye. Ez a megközelítés tükröződik az ún. szociális modell koncepcióban - erről még a későbbiekben lesz szó -, amely szerint a jó egészség nagymértékben függ attól, hogy az egyén milyen mértékben jut hozzá a kulcsfontosságú anyagi forrásokhoz vagy feltételekhez. Egyetértés alakult ki az egyes szerzők között a tekintetben is, hogy az említett források feletti rendelkezés képessége aktív módon befolyásolja az egészséget meghatározó kockázati tényezők alakulását. Egészségegyenlőtlenség akkor keletkezik, amikor ezekhez a forrásokhoz való hozzáférés eltérően alakul az egyes emberek esetében, vagyis egyik ember jobban ki van téve az egészségkockázati tényezőknek, mint a másik. ${ }^{12}$

Az említett szakirodalmi példák arra engednek következtetni, hogy a közösség részvételén keresztül megvalósuló felhatalmazottság ténylegesen képes hozzájárulni egy heterogén csoport tagjainak a kapacitás és kompetencia növekedéséhez. Főleg azok számára érhető el ez tapasztalás, akik közös célokban és problémákban osztoznak, valamint képesek közösségi együtt cselekvésre is. Miután körbejártuk az egyén és a közösség szerepét a kockázati tényezők ellenőrzésében, tekintsük át, mit is jelent a részvétel, a felhatalmazottság, és milyen megközelítések születtek ebben a témában!

\section{A KÖZÖSSÉGALAPÚ EGÉSZSÉGFEJLESZTÉS FOGALMA}

Mielőtt rátérnénk az elméleti megközelítések részletes bemutatására, meg kell ismerkednünk a legfontosabb modellekkel, melyek jól tükrözik a felhatalmazottság értelmezésében fellelhető lényegi különbségeket, mert - mint ahogy azt a későbbiekben látni fogjuk - nem mindegy, hogy az egyén, a szervezet vagy a közösség szintjén megvalósuló felhatalmazottságról beszélünk. A szakirodalom három versengő modellről tesz említést. Ezek alapvető szemléletbeli különbséget tükröznek, és egyúttal kijelölik az egészségfejlesztési beavatkozások célcsoportját is. A legkevésbé komplex és ezért talán a leginkább kézenfekvő megközelítés a „medikális modell” koncepció, amely az egészségfejlesztési beavatkozások során kizárólag az egyénre fókuszál és csak a fizikai környezetben lévő egészségkockázatokat veszi figyelembe, a társadalmi jellegúeket nem. Ezzel szemben a "szociális modell” az egyén egészségét meghatározó társadalmi-gazdasági feltételeket tekinti alapvetőnek. Nem nehéz belátni, hogy a kettő közötti különbség alapvető jelentőségú, különös tekintettel az alkalmazott módszerekre, hiszen az egészségfejlesztési beavatkozás célcsoportjának meghatározásával, egyúttal azt a környezetet is kijelöljük, amelyre a szereplőknek az egészségfejlesztési program végrehajtása során befolyásuk lesz. A "komplementer modell" még ennél is tovább megy. A Dailly és Barr szerzőpáros azt vallja, hogy a még bizonyítottan hatásos beavatkozások sem lehetnek eredményesek az egyén magatartásának befolyásolásában, ha nem teszik lehetővé az egyént befogadó csoport közösségi entitásként való megnyilvánulását, a közösségi lét feltételeinek alakítását. ${ }^{13}$ Első ránézésre talán nem egyértelmű, de a koncepciók mögött jelentős polémia hózódik meg az egészséget meghatározó tényezők jellegével kapcsolatosan.

Miután tisztáztuk a különböző modellek szerepét a fogalomhasználatban, már könnyebb dolgunk van a felhatalmazottság értelmezését illetően is. A felhatalmazottság legáltalánosabb értelemben az egyénnek arra a képességére utal, ami által lehetősége nyílik az egészségi állapotát befolyásoló személyes, társadalmi, gazdasági kockázati tényezők kontrollá-

\footnotetext{
ii A magyarban a stakeholder fordítására használt kifejezés
} 
lására. Kindervatter, Zimmerman, Rappaport és Gutierrez szerint a felhatalmazottság azt a cselekvési képességet is jelenti, amelynek révén az egyén és a közösség képessé válik ezeknek a feltételeknek a befolyásolására. Tehát egyszerre pozitív és proaktív szemben az egészségszolgáltatással, amely reaktív megközelítésű. ${ }^{14,15,16}$

A felhatalmazottság hatókörét alapvetően meghatározza az, hogy kire is irányul. A felhatalmazottságot ezért gyakran a beavatkozás szintje szerint csoportosítják, így beszélhetünk egyéni, szervezeti vagy közösségi szintű felhatalmazottságról.

Az egyéni felhatalmazottság az egyénnek arra a képességére utal, hogy a személyes élete felett kontrollt gyakoroljon. Ennek része az önbecsülés, az önbizalom, amely a személyes kompetenciák megélésén alapul. Ezen túl még magában foglalja a szociális és politikai környezet kritikai megközelítését, a rendelkezésre álló források ismeretét is. Tehát a felhatalmazottságnak ez a megközelítése, amely a személyes hatékonyság és kompetencia kombinációja, végül elvezet a feltételek feletti kontroll érzéséhez. Zimmermann szerint az egyéni felhatalmazottság azt a részvételi folyamatot jelenti, amelynek révén ez egyén befolyást gyakorol intézményekre és döntési alternatívákra. ${ }^{17,18}$ Ugyanakkor ez szorosan kapcsolódik a szervezeti és a közösségi felhatalmazottsághoz, mert az egyén csak ezeken az intézményeken keresztül fejlesztheti a kontroll képességét, a személyes kompetenciáját, a társadalmi és politikai képességeit. ${ }^{19,20}$ Ennél a pontnál azonban meg kell jegyezni, hogy a szerzők többsége a felhatalmazottságnak ezt megközelítését nem tekinti jelentősnek azért, mert ebben a kontextusban igen csekély a valószínűsége annak, hogy az egyén képes megváltoztatni az egészségét befolyásoló szociális és gazdasági környezetet.

A következő részvételi szint, amelyről szót kell ejtenünk, az a szervezeti felhatalmazottság. Ennek fogalma erősen támaszkodik a demokratikus menedzsment koncepcióra. A demokratikusan múködtetett szervezettípust az információk cseréje, a döntéshozatalban való együttmúködés, valamint az egyénnek a szervezeti életet érintő folyamatokba való bevontsága jellemzi. Lényegében úgy hatalmazza fel az egyént, hogy az részévé válik a szervezeti folyamatoknak. Tehát a szervezeti felhatalmazottság Gerschick, Israel, Checkoway és más szerzők szerint úgy befolyásolja az egyént, hogy képessé teszi a szervezeti folyamatokban, a döntésben való részvételre. Ezáltal hatással lehet a tágabb környezetre is, amelyen keresztül a közösségi szintü felhatalmazottság is elérhetővé válik a számára. ${ }^{21} \mathrm{~A}$ felhatalmazott közösségben az egyén és a szervezet számára egyaránt lehetővé válik, hogy képességeit és erőforrásait, elismert szükségleteit koordinált cselekvésben nyilvánítsa ki. ${ }^{30}$ A felhatalmazott szervezet azt is lehetővé teszi, hogy az egyének és a szervezetek a kölcsönös támogatás és konfliktuskezelés révén többletforráshoz jussanak, ami megnöveli a befolyási képességüket az életkörülményeik felett. Ezért kijelenthetjük, hogy a közösségi felhatalmazottság szoros kapcsolatban áll az egyéni és a szervezeti felhatalmazottsággal. Ez az elmélet hasonlatos a szomszédsági felhatalmazottság koncepcióhoz, amely kapacitásról és egyenlőségről szól. A kapacitás jelenti az erő alkalmazását, az egyenlőség pedig a források fair megosztását egy konkrét probléma megoldása során.

A felhatalmazottság szintjeinek áttekintését követően azt is érdemes megvizsgálnunk, hogy melyek azok főbb pontok, eltérések, amelyek körül vita alakult ki a szakemberek között. Lényegében három olyan kérdés merült fel, amelyek vízválasztóak mind elméleti, mind gyakorlati szempontból.

- Az első és az egyik legvitatottabb kérdés az, hogy folyamatként vagy eredményként tekintsünk a felhatalmazottságra. Erre a kérdésre később még visszatérek, most csak arra szeretném felhívni a figyelmet, hogy az egészségfejlesztési programok között nagy különbség van a szerint, hogy már a program végére teljes felhatalmazottsággal ruházza fel a célcsoportot, vagy azt egy hosszabb, a program keretein messze túlnyúló folyamat eredményeképpen képzeli el.

- Hasonlóan markáns vitára okot adó kérdés, hogy a felhatalmazottság személyközi kapcsolatokra vezethető-e vissza, vagy inkább egy tágabb társadalmi, politikai környezetben gyökeredzik, esetleg egy többszintű interakció következménye. 22,23,24,25,26,27,28 Nyilvánvaló, hogy amennyiben társadalmi gyökerü, akkor ehhez olyan felhatalmazottságot kell rendelni, amelynek révén az érdekgazdák képessé válnak a társadalmi környezet befolyásolására. Ha pedig személyközi eredetűnek tekintjük, akkor a felhatalmazottság nem a társadalmi környe- 
zet, hanem a személyközi kapcsolatok megváltoztatására kell, hogy irányuljon. Ez egyúttal teljesen különböző eszközök alkalmazását is jelenti a gyakorlatban. Tehát itt nem kevesebbről van szó, mint hogy milyen kapacitással lássuk el az érdekhordozókat, hogy képessé váljanak az egészségüket befolyásoló tényezők kontrollálására.

- A harmadik és témánk szempontjából egyáltalán nem mellékes kérdéskör, hogy az egyes felhatalmazottsági definíciók hogyan alkalmazhatók a gyakorlatban. ${ }^{29}$ Ez a terület csekély érdeklődésre tartott számot a kutatók körében, csupán a Lavereck és Wallersten szerzőpáros vizsgálta a felhatalmazottság koncepció működésének szervezeti hátterét, alkalmazhatóságát valamint hasznosságát az egészségfejlesztés során. ${ }^{30}$ Ennek a kérdésnek a részletesebb megvitatására a felhatalmazottság folyamat jellegének tárgyalása során még visszatérek.

A közösségi felhatalmazottság koncepciót a 90-es években háttérbe szorították a közösségi kapacitással kapcsolatos elméletek, a közösségi kompetencia kérdésköre, a közösségi kohézióval összefüggő problémák, valamint a szociális tőkével kapcsolatos elgondolások. ${ }^{31,32,33,34,35}$ Ennek ellenére a koncepció egyre elfogadottabbá vált az egészségfejlesztés terén is, különös tekintettel a szegénység, az egészségegyenlőtlenség felszámolására tett erőfeszítések során, amely viták - ahogy azt Wilkinson is állítja - korábban nélkülözték a szociális dimenzió, a hatalomkonverzió, a hatalomnélküliség hatásának elemzését. ${ }^{36}$ Azóta világossá vált a szakemberek előtt, hogy csak akkor vagyunk képesek befolyásolni az egyéni élethelyzetünket, ha sikerül elérni azokat a társadalmi változásokat, amelyek révén megszüntethető az egyén hatalomnélkülisége. Ez utóbbi fogalom, úgy tûnik, továbbra is az egyik legfontosabb tényezője marad a közösségi felhatalmazottság körüli vitáknak. E közösségi szükséglet kielégítése révén válnak ugyanis képessé az egyének az életkörülményeiket befolyásoló tényezők kontrollálására.

A közösségi felhatalmazottság fogalmának részletes kifejtéséhez, megértéséhez meg kell vizsgálnunk, hogyan is múködik a felhatalmazottság a gyakorlatban, milyen problémák merülnek fel a közösségalapú részvétel megvalósítása során. Ehhez tematikusan sorra kell vennünk azokat a szempontokat, amelyek tisztázása közelebb visz a felhatalmazottság gyakorlatban történő alkalmazásához. A következőkben ezt a feladatot végezzük el, amihez megvizsgáljuk a következőket: a) Mit jelent a közösség fogalma az egészségfejlesztés során? b) Milyen tényezők befolyásolják a közösségi felhatalmazottságot? c) Folyamatnak vagy inkább eredménynek tekinthető-e a közösségi felhatalmazottság? d) Hogyan fejlesszük a felhatalmazottságot az egészségfejlesztési programok megvalósítása során? e) Hogyan befolyásolja a felhatalmazottság a különböző érdekgazdák szerepét és felelősségét? Mindenekelőtt vizsgáljuk meg a közösség fogalmát.

\section{MIT JELENT A KÖZÖSSÉG FOGALMA AZ EGÉSZ- SÉGFEJLESZTÉS SORÁN?}

Kit is tekintünk közösségnek, milyen elvárásokat fogalmazzunk meg velük szemben ahhoz, hogy felhatalmazott célcsoportként tekinthessünk rájuk? Ezeknek a kérdéseknek a tisztázása nélkülözhetetlen, ha közösségalapú egészségfejlesztésben gondolkodunk. Lewin meghatározása szerint, aki a csoportot a közösség szinonimájaként használta, „a csoport lényege nem a tagok hasonlósága vagy különbözősége, hanem kölcsönhatása, egymástól való függése". ${ }^{37}$ Ward, Israel és munkatársai, valamint Bell és Newby is egyetértenek abban, hogy egy közösség lehet akár alapvetően heterogén összetételű is, és állhat eltérő érdekű egyénekből, akik céljaik megvalósítása érdekében közösen léphetnek fel. ${ }^{38,39,40}$ Zakus és Lysack ezzel szemben inkább azt tartja fontosnak tisztázni, hogy ki is valójában a legitim képviselője egy közösségnek. ${ }^{41}$ Szerintük azok, akiknek van idejük és energiájuk, hogy bevonódjanak a csoport munkájába, de rögtön hozzáteszik azt is, hogy amennyiben a tevékenységük nélkülözi a közösség támogatását, csupán domináns elitnek tekinthetők. Tehát a közösség legitim képviseletéhez szükséges a tagok hozzájárulása, támogatása. Ugyanakkor elismerik, hogy a nem heterogén, vagyis a hagyományos közösségek sem feltétlenül képesek vagy hajlandóak egyeztetett közösségi lépésekre közös céljaik megvalósítása érdekében. Ezért végül arra a következtetésre jutnak, hogy a heterogén összetétel nem lehet akadálya a közösségi identitás kialakulásának, a közösen kitűzött célok követésének. Azt is állítják, hogy egy újonnan létre- 
jött, másképpen fogalmazva egy nem tradicionális közösség is képes lehet olyan egészségfejlesztési programcélok megfogalmazására, amelynek révén felhatalmazottsághoz juthatnak. Ezek nagyon fontos megállapítások, mert teret adnak a közösség tágabb értelmezéséhez. A közösség megléte csupán kiindulópont, azaz szükséges, de nem elégséges feltétele a közösségi részvétel gyakorlásának, ehhez még további tényezők is szükségesek. Tekintsük át, melyek ezek!

\section{MILYEN TÉNYEZŐK BEFOLYÁSOLÁK A KÖZÖS- SÉGI FELHATALMAZOTTSÁGOT?}

Az elmúlt évtizedekben számos elemzés látott napvilágot a közösségi felhatalmazottságot befolyásoló tényezőkről, azonban ezek nem alkottak koherens egészet. Laverack foglalta először rendszerbe a közösségi felhatalmazottsággal kapcsolatosan megfogalmazott korábbi elméleteket. Egymástól kilenc jól elhatárolható szervezeti tényezőt különböztetett meg, amelyek véleménye szerint hatással vannak a közösségi felhatalmazottság alakulására. Ezek a következők: (i) participáció, (ii) vezetés, (iii) problémafeltárás, (iv) szervezeti struktúra, (v) forrásallokáció, (vi) másokhoz való viszony, (vii) „a miért kérdés", (viii) programmenedzsment és (ix) a külső szervezetek szerepe a közösségi felhatalmazottságban. ${ }^{42}$ Everson és más kutatók is határozottan állítják, hogy a felsorolt szervezeti jellemzők jelentik a kapcsolatot az interperszonális elemek - például az egyéni kontroll képessége, a bizalom, a közösség kohéziója, valamint a kontextuális elemek - között. Ez utóbbiak lehetnek politikai természetűek, vagy szociokulturálisak, továbbá gazdasági környezetből fakadóak egyaránt. ${ }^{43,44,45,46,47}$ A Laverack által alkalmazott szervezeti megközelítés előnye, hogy az egyén és a csoport számára egyaránt lehetővé válik, hogy közösen megfogalmazott társadalmi és politikai célok elérése irányába mobilizálja önmagát. Más kutatók, így Taylor szerint, ez az értelmezés arra is módot ad, hogy úgy tekintsünk a szervezetre magára, mint amely jogosult képviselője a közösségi felhatalmazottság társadalmi aspektusának. Például itt említhető, ha már létezik egy szervezetben funkcionális vezetési módszer - melyet megszilárdult szervezeti struktúrák is támogatnak, továbbá amely a szervezeti tagok aktív részvételével működik, tehát már bizonyították, hogy képesek források mobilizálására -, akkor ez egyúttal egy olyan közösségről is számot ad, amely már rendelkezik az erős közösségi támogatás egyes elemeivel.

\section{FOLYAMATNAK VAGY INKÁBB EREDMÉNYNEK TEKINTHETŐ A KÖZÖSSÉGI FELHATALMAZOTT- SÁG?}

A szervezeti tényezők áttekintését követően figyelmünket ismét a már korábban érintett vitatémára fordíthatjuk, nevezetesen, hogy miképpen tekintsünk a közösségi felhatalmazottságra: úgy, mint folyamatra vagy inkább úgy, mint eredményre. Ennek eldöntése nem pusztán elméleti jelentőségú, ugyanis következménye van a gyakorlatra nézve is, hiszen már az egészségfejlesztési beavatkozás előtt el kell döntenünk, hogy felhatalmazottsági szempontból mit tartunk eredménynek az egészségfejlesztési program végén.

Mindkettőre (folyamat és eredmény megközelítés) bőséges bizonyíték található az irodalomban. $\mathrm{Ha}$ eredménynek tekintjük, akkor az hosszú távú, az egyén és a közösség kölcsönhatásában létrejövő szervezeti - legalábbis társadalmi és politikai értelemben megvalósuló - változásként értelmezhető, amely Raeburn szerint legkevesebb hét év, de inkább hosszabb időszak alatt alakul ki. ${ }^{48} \mathrm{Az}$ egészségfejlesztési programok többsége viszont ennél rövidebb futamidejü. Bainstow mutat rá arra a tényre, hogy a legtöbb esetben az az időszak, amelynek végére a közösség alkalmazhatná az új kompetenciát, a közösségi felhatalmazottságot, messze túlnyúlik az egészségfejlesztési program befejezésén. Így valójában e programok keretében a közösségek nem tapasztalhatják meg a felhatalmazottság mibenlétét a maga teljességében. ${ }^{49}$ Azonban ez semmiképpen nem tekinthető kudarcnak, inkább azt mutatja, hogy a közösségi felhatalmazottság kialakulása egy hosszú folyamat eredménye és irreális az az igény, hogy az egészségfejlesztési beavatkozással egy időben teljes körű felhatalmazottság jöjjön létre. Mindez azonban egyáltalán nem jelenti azt, hogy kísérletet sem kell tenni az elérésére. Számos példa van arra, hogy ilyen körülmények között is, akár egyéni, akár közösségi szinten, de mindenképpen létrejöhet bizonyos pszichológiai és társadalmi felhatalmazottság, amely alatt az önbizalom növe- 
kedését, vagy a bizalmi légkör kialakulását, közösségi kompetenciák növekedését értjük. ${ }^{50}$

Tehát kijelenthetjük, hogy amennyiben a közösségi felhatalmazottságot tekintjük végső célnak, akkor az olyan tevékenységek, mint a kapacitás- és kompetenciafejlesztés értelemszerűen nem vehetők figyelembe eredményként, hiszen ezek csupán egyéni, legfeljebb szervezeti szintre vonatkoznak. Az elmondottakból is látszik, hogy az egyéni szinten megvalósuló felhatalmazottság más eredményeket produkál, mint a közösségi szintű. Azonban még ezek az igen korlátozott jelentőségű eredmények is értékesek lehetnek, mert lépcsőfokot jelentenek a közösségi felhatalmazottság felé.

Zimmermann hívja fel a figyelmet arra, hogy az univerzális, az egyes beavatkozási szintek között különbséget nem tevő megközelítések zavart okozhatnak a felhatalmazottság fogalmának megértésében különösen, ha azt statikusan és nem dinamikusan értelmezzük. Úgy véli, hogy a közösségi felhatalmazottság univerzális célként való értelmezése nem reális, mert az nem ugyanazt jelenti az egyén, a szervezet és a közösség számára. ${ }^{51}$

Éppen az előbb bemutatott érvelés miatt a közösségi felhatalmazottságra az irodalomban leggyakrabban ún. dinamikus kontinuumként tekintenek, amely magába foglalja: (i) a személyes felhatalmazottságot, (ii) a kiscsoportok dinamikus fejlődését, (iii) a közösségi szervezeteket, (iv) a partnerséget, (v) társadalmi és politikai tevékenységeket. ${ }^{52,53,29}$ E szerint az értelmezés szerint, amely kontinuumként, folyamatként tekint a közösségi felhatalmazottságra, az csak lépésenként javítható, mégpedig annak az erőfeszítésnek az eredményeképpen, amikor az egyéni cselekvések a kollektív cselekvések irányába mozdulnak el.

A közösségi felhatalmazottság folyamatként való értékelése ugyanakkor jelentősen befolyásolja a koncepció alkalmazhatóságát is. Azt már láthattuk, hogy az eredményként való értelmezés csak korlátozott lehet annak időtől való függősége miatt. Azonban ha a közösségi felhatalmazottságot folyamatként értelmezzük, akkor lehetővé válik az egyéni szinten megjelenő kapacitás-, képesség- és kompetenciafejlesztés összekapcsolása a közösségi szintű egészségfejlesztéssel, amely együtt járhat a személyközi kapcsolatok általános javulásával, ami pedig közelebb vihet az egészségpolitikai célok megvalósulásához is. Ez a Laverack és Walleistein szerzőpáros által képviselt definíció abból a szempontból is használhatóbb, hogy betekintést enged abba a folyamatba, amikor az egészségfejlesztési program képessé teszi, felhatalmazza az egyént, a közösséget arra, hogy maximalizálhassa kollektív cselekvőképességét az egészséget meghatározó társadalmi és gazdasági tényezők kontrollálása érdekében. ${ }^{30}$ Mindezek jelentős mértékben befolyásolják a közösségi felhatalmazottsággal kapcsolatos, a programok megvalósítása során kitűzött szervezeti célok gyakorlati megvalósíthatóságát. Az alábbiakban ezeket a tényezőket veszem sorra.

\section{HOGYAN FEJLESZTHETJÜK A FELHATALMAZOTT- SÁGOT AZ EGÉSZSÉGFEJLESZTÉS SORÁN?}

Láthattuk, hogy a közösségi felhatalmazottság lényege a befolyásolásban van, ezért a helyzetfeltárás, a szerepek tisztázása még nem elégséges eszköz a felhatalmazottság sikerességének megítéléshez, így ez önmagában az egészségfejlesztési program érdekgazdáinak a felhatalmazottsággal kapcsolatos eredményeit sem tükrözi. Ugyanakkor az érdekgazdák által beazonosított információk társadalmi, gazdasági akcióvá alakítása már annál beszédesebb indikátor. Ez a cél, mint azt korábban láthattuk, a személyközi viszonyok befolyásolásán keresztül érhető el, ezért ennek mértéke nagyon jó ismérve lehet a felhatalmazottság eredményességének. A befolyás kialakulásához azonban más tényezők is hozzájárulnak, így szükség lehet stratégiai gondolkodásra, tervezésre és olyan eszközök alkalmazására, mint például a projekttervezéshez nélkülözhetetlen logikai keretmátrixra, amely részletesen tartalmazza a közösségi felhatalmazottsággal kapcsolatos teendőket. Cracknell véleménye szerint a logikai keretmátrix kiváló lehetőséget teremt az olyan célok kitűzésére, azoknak a közösségi felhatalmazottságot mérő indikátoroknak az előzetes megfogalmazására is, amelyek képesek az előrehaladás mérésére, amelyek egyúttal a közösségi felhatalmazottsággal kapcsolatos kockázatokat és várakozásokat is képesek előre jelezni. ${ }^{54}$ Cracknellhez hasonlóan Goodman is fontosnak találja a logikai keretmodell alkalmazását, amely véleménye szerint lehetővé teszi a közösség számára azt is, hogy a kívánatos folyamatot illetően megfogalmazza saját oksági modelljét, továbbá hogy a körül- 
mények megváltoztatása révén elősegítse az egészségfejlesztési célokkal kapcsolatos bizalom kialakulását, megerősödését az érintett közösségben. ${ }^{55} \mathrm{Az}$ egyes szakértők tehát egyetértenek abban, hogy a logikai keretmátrix révén a közösségi felhatalmazottsággal kapcsolatosan megfogalmazott célok mérhetővé, egyszersmind ellenőrizhetővé válnak. A felhatalmazottság eredményességéhez azonban arra is szükség van, hogy tiszta, átlátható szerepviszonyok alakuljanak ki az érdekgazdák között, ezért az alábbiakban erről lesz szó.

\section{HOGYAN BEFOLYÁSOLA A FELHATALMAZOTT- SÁG A KÜLÖNBÖZŐ ÉRDEKGAZDÁK SZEREPÉT ÉS FELELŐSÉGÉT?}

Korábban már volt róla szó, hogy a felhatalmazottság megváltoztatja a személyközi viszonyokat, de nem vizsgáltuk azt, hogy ez milyen folyamat keretében történik. Hogy világosan lássunk ebben a kérdésben is, tekintsük át a szerepviszonyok változását a felhatalmazottság folyamán! Amikor az egyén vagy közösség gyakorolja a felhatalmazottságát, befolyásolja az eseményeket, akkor lényegében újradefiniálja a szerepviszonyokat az elsődleges és másodlagos szereplők között. Erre jó példa Patton megfigyelése, aki észrevette, hogy a külső szervezetek szerepére gyakran tekintenek úgy, mint szakértőre vagy értékelőre, aki elbírálja, mi értékes és ki érdemes. ${ }^{56} \mathrm{~A}$ felhatalmazott környezetben azonban ez a szerep facilitátor szereppé változik, amely képessé teszi, vagy ahogy Flettermann állítja, támogatja és vezeti az elsődleges érdekgazdákat. ${ }^{57} \mathrm{Az}$ egészségfejlesztők feladata tehát nem lehet más, mint az egyén és csoport képességének fejlesztése, hogy az érdekgazdák megszerezhessék és megragadhassák azt a hatalmat, befolyást, amely által képesek lesznek kontrollálni környezetüket és egészségüket. Széles körű konszenzus alakult ki a szerzők között a tekintetben is, hogy a kritikai megközelítés már önmagában is felhatalmazottságot eredményez azzal, hogy elvezet az elsődleges érdekgazdák kapacitásának, kompetenciájának bővüléshez. Ez könnyen érthető, hiszen a kritikai gondolkodáshoz hozzátartozik az információk összegyüjtésének, feldolgozásának a képessége is. Az átalakuló szerepek később állandósulnak, szabályokká válnak. Nemritkán az így kialakult programszabályokat dokumentumban is rögzítik. Ennek az az előnye, hogy amikor kialakult a konszenzus a szabályok fontosságát illetően, onnan kezdve már hivatkozásként tekintettek rá, amely a későbbiekben iránymutatásképpen szolgál a szerepeket és a felelősséget illetően. Megállapíthatjuk, hogy a felhatalmazottság a szerepviszonyok változása, intézményesülése révén egy dinamikus folyamatot indít el, amely végül visszahat magára a felhatalmazottságra is.

\section{ÖSSZEGZÉS}

Írásomban a közösségi felhatalmazottság eltérő megközelítéseit kívántam bemutatni. Irodalmi források feldolgozását követően megállapítható, hogy mind a fogalomhasználatot, mind annak tényleges tartalmát tekintve egymástól kisebb-nagyobb mértékben eltérő koncepciók alakultak ki. Első ránézésre ezek a különbségek jelentéktelennek tűnhetnek, azonban az egészségfejlesztési programok megvalósítása során már jelentős eltéréseket eredményezhetnek a résztvevők felhatalmazottságát illetően. A felhatalmazottság fogalma hosszú fejlődési folyamaton ment keresztül. Mára azonban kialakult egy közös értelmezési keret, amely a) a különböző típusú és szintű részvételi formákat foglalja magában (az egyéni, a szervezeti és a közösségi szinten megvalósuló döntéshozatali formák); b) olyan munkamódszert képvisel, amely előnyben részesíti a kapacitásfejlesztést célzó részvételt (úgymint közösségi kapacitásfejlesztést és közösségfejlesztést); c) feltárja a közösségben meglévő személyek közötti részvételen alapuló kapcsolatokat, amelyek az egészséggel, a jólléttel kapcsolatosak; d) mobilizálja a közösségi erőforrásokat.

Zakus és Lysack szerint annak ellenére, hogy csupán kevés bizonyított tény áll rendelkezésünkre a közösségi felhatalmazottság egészségfejlesztéssel kapcsolatos hatását illetően, mégis széleskörűen elfogadott az a vélekedés, hogy annak számos fontos eredménye van. ${ }^{41}$ Függetlenül attól, hogy ez mekkora - tekintve a motivációs hatását és annak eszközjellegét -, a haszna mindenképpen fontos mind az egyén, mind a szervezetek és a közösségek számára. ${ }^{58,59,60,5}$ A legnagyobb haszna azonban a fejlődő demokráciában, a források mobilizálódásában, holisztikus és integrált rendszerek kialakulásában, a jobb döntéshozatal elérésben mutatkozik 
meg. A WHO vonatkozó dokumentumai egyértelmúen arra utalnak, hogy a közösségi felhatalmazottság hatékonyabb egészségszolgáltatásokat és fenntarthatóbb egészség-magatartást eredményez, nem kis részben annak köszönhetően, hogy a közösség sajátjának érzi a rá vonatkozó egészségfejlesztési programot. ${ }^{6}$

Az irodalom áttekintését követően elmondhatjuk, hogy az Ottawai Nyilatkozat elsőként túzte napirendre az egészségfejlesztés közösségalapú múve- lését, és teret nyitott olyan gondolatok előtt, amelyek később hozzájárultak a fogalom elterjedéséhez és átültetéséhez a gyakorlatba. Az e területen felhalmozott ismeretanyag kiváló lehetőséget teremt hazánk számára is, hogy csatlakozzon az Ottawai Nyilatkozat szellemiségéhez, és a népegészségügy intézményi reformja során forrásként használja azt a bőséges elméleti és gyakorlati tudást, amelyet az egészségfejlesztésben előttünk járók gyűijtöttek össze.

\section{HIVATKOZÁSOK}

\footnotetext{
${ }^{1}$ Az Ottawai Egészségfejlesztési Charta. In: Az egészségfejlesztés alapelvei. http://regi.oefi.hu/alapelvek. pp 9-14. (Elérve: 2017.11.13.)
}

${ }^{2}$ Dzsakartai Nyilatkozat. In: Az egészségfejlesztés alapelvei. http://regi.oefi.hu/alapelvek.pdf. pp 29-34. (Elérve: 2017.11.13.)

${ }^{3}$ WHO Regional Office for Europe HEALTH 21 - The Health for All Policy Frame-work for the European Region. WHO Regional Office for Europe, Copenhagen, 1998.

${ }^{4}$ Bracht N, Tsouros A. Principles and strategies of effective community participation. Health promotion International. 1990;5:199-208.

${ }^{5}$ Smithies J, Webster G. Community Involvement in Health: From Passive Recipients to Active Participants. Ashgate, Aldershot, 1998.

${ }^{6}$ WHO Regional Office for Europe. Community Participation in Local Health and Sustainable Development: Approaches and Techniques. Centre for Urban Health, WHO Regional Office for Europe, Copenhagen, 2002. http://apps.who.int/iris/bitstream/10665/107341/1/E78652.pdf (Elérve: 2017.11.30.)

7 Israel BA, Schurman SJ. Social support, control, and the stress process. In: Glanz K, Lewis F, Rimer B (eds.). Health Behaviour and Health Education: Theory, Research and Practice. San Francisco, CA, Jossey-Bass, 1990.

${ }^{8}$ Haan MN, Kaplan GA, Camacho-Dickey T. Poverty and health: Prospective evidence from the Alameda County Study. Am J Epidemol. 1987;125:989-98.

${ }^{9}$ Israel BA, Rounds KA. Social networks and social support: A synthesis for health educators. Advanced Health Education Promotion. 1987;2:322-51.

${ }^{10}$ James C. Empowering Communities in the Development Process: Participatory Rural Appraisal as an Approach. University of Bristol, Bristol, 1995.

${ }^{11}$ Rifkin SB. Community participation in maternal and child health/family planning programmes. World Health Organisation, Geneva, 1990.

${ }^{12}$ Csizmadia P. Az egyenlőtlenségek alapvető társadalmi okai és az elmélet alkalmazási lehetőségei az egészségügyi szakpolitikákban. Egészségfejlesztés. 2017,58(2)17-9. doi:http://dx.doi.org/10.24365/ef.v58i2.168.

${ }^{13}$ Dailly J, Barr A. Understanding a Community-led Approach to Health Improvement, 2008.

${ }^{14}$ Kindervatter S. Nonformal education towards empowering. Chapter VII. In: Nonformal Education as an Empowering Process. Amherst, MA, Center for International Education, 1978.

${ }^{15}$ Gutierrez LM. Coping with Stressful Life Events. An Empowerment Perspective. Working Paper. School of Social Work, University of Michigan, Ann Arbor, MI, 1988.

${ }^{16}$ Zimmerman MA, Rappaport J. Citizen participation, perceived control, and psychological empowerment. Am J Community Psychol 1988; 16:725-750.

17 Zimmerman MA. Empowerment theory. Psychological, organizational and community levels of analysis, In: Rappaport J, Seidman E (eds.). Handbook of Community Psychology. New York, 2000.

18 Zimmerman MA. Taking aim on empowerment research: On the distinction between psychological and individual conceptions. Am J Community Psychol. 1990;18:169-77.

${ }^{19}$ Kieffer CH. Citizen empowerment: A developmental perspective. Prev Hum Serv. 1984;3:9-36.

20 Schulz AJ, Israel BA, Zimmerman MA, Checkoway BN. Empowerment as a multilevel construct: Perceived control at the individual, organizational and community levels. Health Education Research. 1995;10:309-27. 
${ }^{21}$ Gerschick TJ, Israel BA, Checkoway BN. Means of Empowerment in Individuals, Organizations, and Communities. Report on a retrieval conference, Ann Arbor, University of Michigan, 1990. https://deepblue.lib.umich.edu/bitstream/handle/2027.42/51259/493.pdf; sequence=1 (Elérve: 2017.11.13.)

22 Bernstein E, Wallerstein N, Braithwaite R, et al. Empowerment forum: a dialogue between guest editorial board members. Health Education Quarterly. 1994;21:281-94.

${ }^{23}$ Torre D. Empowerment: structured conceptualisation and instrument development. PhD thesis, Cornell University, 1986.

${ }^{24}$ Rappaport J. Terms of empowerment/exemplars of prevention. Toward a theory of community psychology. American Journal of Community Psychology. 1987;15:121-47.

${ }^{25}$ Swift C, Levin G. Empowerment: an emerging mental health technology. Journal of Primary Prevention. 1987;8:71-94.

${ }^{26}$ Friedmann J. Empowerment: The Politics of Alternative Development. Blackwell Publishers, Oxford.

${ }^{27}$ Craig G, Mayo M (eds.) Community Empowerment. A Reader in Participation and Development. Zed Books, London, 1995.

${ }^{28}$ Wallerstein N. Powerlessness, empowerment and health. Implications for health promotion programs. American of Health Promotion. 1992;6:197-205.

${ }^{29}$ Rissel C. Empowerment: the holy grail of health promotion? Health Promotion International. 1994;9:39-47.

30 Laverack G, Walleistein N. Measuring Community empowerment: a fresh look at organisational domains. Health Promotion International. 2001;16:179-85.

${ }^{31}$ Goodman RM, Speers MA, McLeroy K, et al. Identifying and defining the dimensions of community capacity to provide a basis for measurement. Health Education and Behavior. 1998;25:258-78.

32 Eng E, Parker E. Measuring community competence in the Mississippi delta: the interface between programme evaluation and empowerment. Health Education Quarterly. 1994;21:199-220.

${ }^{33}$ Geyer S. Some conceptual considerations on the sense of coherence. Social Science Medicine. 1997;44:1771-9.

${ }^{34}$ Putnam RD. Bowling alone: Americas declining social capital. J Democracy. 1995;6:65-78.

${ }^{35}$ Modra C. Exploring social capital: levels of participation, trust and health in a suburban region of Adelaide, South Australia. Celebrating Public Health: Decades of Development, Decades of Opportunity, Public Health Association of Australia, Hobart, 1998.

${ }^{36}$ Wilkinson RG. Income inequality and social cohesion. Am J Public Health. 1997;8:104-6.

${ }^{37}$ Pataki Ferenc (szerk.). Csoportlélektan. Budapest, Gondolat Kiadó, 1980. 735 o.

38 Bell C, Newby H. Community Studies. George Allen and Unwin, London, 1978.

${ }^{39}$ Ward J. Community development with marginal people: the role of conflict. Community Development Journal. 1987;22: 18-7.

${ }^{40}$ Israel BA, Checkoway B, Schultz A, Zimmerman M. Health education and community empowerment: conceptualizing and measuring perceptions of individual, organizational and community control. Health Education Quarterly. 1994;21:49-170.

${ }^{41}$ Zakus JDL, Lysack CL. Revisiting community participation. Health Policy and Planning. 1998;13:1-12.

42 Laverack G. Addressing the contradiction between discourse and practice in health promotion. PhD thesis, Deakin University, Melbourne, Australia, 1999.

${ }^{43}$ Everson SA, Lynch JW, Chesney MA, et al. Interaction of workplace demands and cardiovascular reactivity in progression of carotid atherosclerosis: population based study. British Medical Journal. 1997;314:553-8.

${ }^{44}$ Geyer S. Some conceptual considerations on the sense of coherence. Social Science Medicine. 1997;44:1771-9.

${ }^{45}$ Asthana S. Community participation in health and development. In: Phillips D, Verhasselt Y (eds.). Health and Development. Routledge, London, 1994.

${ }^{46}$ Gordon G. Participation, empowerment and sexual health in Africa. In: Craig, G. and Mayo, M. (eds.). Community Empowerment. A Reader in Participation and Development. Zed Books, London, 1995, pp. 181-93.

${ }^{47}$ Taylor V. Social reconstruction and community development in the transition to democracy in South Africa. In: Craig G, Mayo M (eds.). Community Empowerment: A Reader in Participation and Development. Zed Books, London, 1995; pp.168-80.

${ }^{48}$ Raeburn J. How effective is strengthening community action as a strategy for health promotion? ParticiACTION. No. 3. University of Toronto, Toronto, 1993.

${ }^{49}$ Baistow K. Liberation and regulation? Some paradoxes of empowerment. Critical Social Policy. 1995;42:34-46.

50 Zimmerman MA. Taking aim on empowerment research: on the distinction between individual and psychological conceptions. American Journal of Community Psychology. 1990;18:169-77.

${ }^{51}$ Zimmerman MA. Psychological empowerment: issues and illustrations. American Journal of Community Psychology. 1995;23:581-99.

52 Jackson T, Mitchell S, Wright M. The community development continuum. Community Health Studies. 1989;8:66-73. 
53 Labonte R. Health Promotion and Empowerment: Reflections on Professional Practice. Health Education Quarterly. 1994;21:253-68.

${ }^{54}$ Cracknell BE. Evaluating development aid. Evaluation. 1996;2:23-33.

55 Goodman RM. Evaluation of community-based health programs: an alternate perspective. In: Schneiderman N, Speers $\mathrm{M}$, Tomes $\mathrm{H}$, et al. (eds.). Integrating Behavioural and Social Sciences with Public Health. American Psychological Association Press, Washington DC, 2000.

56 Patton MQ. Toward distinguishing empowerment evaluation and placing it in a larger context. Evaluation Practice. 1997;18:147-63.

${ }^{57}$ Fetterman DM, Kaftarian SJ, Wandersman A (eds.). Empowerment Evaluation. Knowledge and Tools for Self-Assessment and Accountability. SAGE publications, 1996.

58 Jewkes F, Murcott A. Community representatives: representing the 'community'? Social Science and Medicine. 1998;46:843-58.

${ }^{59}$ Kahssay H, Oakley, P (eds.). Community Involvement in Health Development: A Review of the Concept and Practice (Public Health in Action, No. 5).World Health Organization, Geneva, 1999.

${ }^{60}$ Morgan L. Community participation in health: perpetual allure, persistent challenge. Health Policy and Planning. 2001;16:221-30. 